\title{
Improving Students' Motivation to Learn English by Serving English Book with Local Wisdom
}

\begin{abstract}
Nining Ismiyani ${ }^{1 *}$
${ }^{1}$ Fakultas Keguruan dan IImu Pendidikan, Universitas Tanjungpura, Pontianak, Indonesia

*e-mail: niningismiyani@untan.ac.id

Abstract

In improving English language skills, reading serves as a supportive activity. Reading is fundamental to improve students' vocabulary in order to facilitate their speaking and writing skills. However, one of the barriers that students face in reading contents obtained from overseas references is the level of reading difficulty which is classified as quite high that it reduces reading motivation. This study aims to develop an English reading comprehension book that contains the local values to motivate students in learning English as well as an as attempt to preserve local culture among millennial students who have massively been exposed to western lifestyles. This study used a Research and Development $(R \& D)$ approach with the ADDIE (Analysis, Design, Development, Implementation, and Evaluation) model. However, only the initial three stages out of five will be discussed. 187 participants studying at a university in West Kalimantan were invited online to take part in the needs analysis stage and initial evaluation. The research resulted in a book with an ISBN in accordance to the participants' needs and points of view in the analysis stage. Initial evaluation reveals that the book is interesting and easier to read that it is expected to increase motivation of English learners.
\end{abstract}

Keywords: Traditional Markets, Teaching Materials, Development, Extensive Reading

\section{Introduction}

In improving English language skills, reading serves as a supportive activity. Reading is fundamental to improve students' vocabulary in order to facilitate their speaking and writing skills (Hung \& Ngan, 2015). However, one of the barriers that students face in reading contents obtained from overseas references is the level of reading difficulty which is classified as quite high that it reduces reading motivation. The low motivation is not only the case with motivation to read but also motivation to learn English. Reading materials that are oriented towards different cultures of other countries, in addition to the high level of language difficulty, have made it difficult for the learners to digest (Chen \& Chen, 2015; Davoudi \& Yousefi, 2015). Therefore, it is necessary to provide reading materials that are familiar to the reader. Reading materials whose contents are closely related to the reader's culture can facilitate the reader in absorbing the information presented in English. Designs that promote a culture relatable to the reader improve comprehension (Nurfatuhiyah, 2017). Furthermore, understanding a reading text is not only understanding the literal meaning of each word but also understanding the unity of the text that is inseparable from the integration with prior knowledge or basic knowledge brought by each reader when reading as well as the integration of the reader's meta cognitive competence (Ahmadi \& Pourhossein, 2012). Therefore, raising a local culture in accordance with the basic knowledge of the reader is important, and in this case this book touches on the traditional market culture that is closely related to the people of Pontianak, in particular and Indonesia in general.

Integrating local culture is one of the best strategies in teaching English to speakers of English as a Foreign Language (Florentino, 2014). He incorporated local culture into development of English language learning materials and the results showed that local culture is helpful in learning English. Furthermore, Folentino (Florentino, 2014) also stated that integrating local culture can help to develop the culture itself. Integration of local wisdom is

\footnotetext{
${ }^{*}$ Corresponding author.

Received February 27, 2021; Accepted May 15, 2021; Available online September 25, 2021

Copyright @ 2021 by Author. Published by Universitas Pendidikan Ganesha.
}

Jurnal Pendidikan Indonesia (JPI) | 453 
proven to enhance student learning outcomes as well as to develop students' character (Anggraini \& Kusniarti, 2017; Hadi, 2017; Khoiri, 2016).

In 2012, Kusuma successfully developed teaching material for elementary school students with the theme of tourism. The book entitled Tourism Area was then distributed for evaluation. After carrying out various series of validations and evaluations, The book that promotes cultural values is effective in improving students' reading skills (Kusuma, 2012). The most recent research which also used local wisdom as the main theme in developing English teaching materials got a score of 3.76 from various education practitioners and linguists (Arifani, 2016). These results indicate that integrating local wisdom into reading material in English is an effective strategy. On the contrary, previous study developed an English book that contains stories about local fairy tales (Agustina \& Harahap, 2018). Then, they revealed the fact that students had difficulty understanding tales of foreign origin and stated that students preferred to read Indonesian fairy tales that have been adapted into English. Therefore, it is important to raise the topic of cultural values that are recognizable to the readers. Authentic reading texts must be centered on communicative outcomes rather than just a practice of using the language (Tomlinson, 2011). By integrating culture into reading texts, it is expected that readers or English learners will have a better understanding of the texts which will subsequently boost their motivation to learn and improve their mastery of English.

Currently, English reading materials with local wisdom in Indonesia are mostly available for primary and secondary students, but not for those from tertiary education (Agustina \& Harahap, 2018; Florentino, 2014; Kusuma, 2012; Relin et al., 2018; Saputri, 2020; Suastra et al., 2017). It is not surprising since one of the functions of a supplementary book based on the textbook is to develop materials and programs in the school curriculum (Muslich, 2010). Therefore, to fill the gap, an initiative was taken to prepare a book that contributes to help improve the process of the teaching and learning of English, particularly in the university level. In fact, the teaching material modules available to English students and teachers are quite limited. A study was conducted to create an English book that attracts reading interest and motivates the reader to learn English. Supplementary books are an important component in increasing learning motivation and at the same time improving the user's learning outcomes (Rena, 2014). Local wisdom can be substantial to create a reliable teaching material (Albantani \& Madkur, 2018; Anzar et al., 2018). The book in question is entitled "Popular Traditional Market in Pontianak". This book covers the wisdom of local culture that is inherent in the Indonesian society, namely the culture of traditional markets with unique contents which include products sold in the markets and the actors involved, and other things related to Traditional Markets.

Local wisdom can be organized as learning models, teaching materials, and even assessment (Parmin et al., 2016; Toharudin \& Kurniawan, 2016). "Popular Traditional Markets in Pontianak" as teaching/enrichment materials will supplement the English reading comprehension books that have been used so far. The book resulted from the research can be used for learning English inside and outside the classroom and, therefore, beneficial to both English teaching staff and students. The low level of English mastery in the widely open opportunities for global competition, of course, has been a concern to the education observers in Indonesia. Contributing to helping achieve Indonesia's success is a common goal. Therefore, contributing time and energy to the making of this book is urgent in order to enrich reading material selection with the aim of creating an effective English learning source both inside and outside the classroom.

Extensive Reading has been authenticated and widely acknowledged for its beneficial contributions for EFL learning (Mori, 2015; Waring \& McLean, 2015). Several previous studies have reported the benefits of extensive reading, are among others, increasing mastery of vocabulary and reading speed (Aka, 2019; He, 2014; Liu \& Zhang, 2018; Renandya \& Jacobs, 2016; Suk, 2017). In Japan, extensive reading programs are believed to be able to overcome the limitations of English language input (Aka, 2019). Extensive reading can provide remarkable input for students (Renandya \& Jacobs, 2016). 
Although many experts agree on the potential benefits from extensive reading, there is still debate as to how long the program should take. In general, it might be thought that the longer this program lasts, the better it will be for the students' English language skills (Aka, 2019; Grabe, 2009; Nakanishi, 2015; Renandya \& Jacobs, 2016). However, meta-analysis of 21 previous studies revealed an interesting fact (Liu \& Zhang, 2018). They investigated the effects of extensive reading on students' acquisition of new vocabulary and claimed that the best duration of the program is one semester or less than three months. A study on the programs being carried out for two semesters or more did not show any significant changes in the development of students' vocabulary. They argued that the focus of their research on vocabulary may have contributed to this outcome. Therefore, one semester is enough to memorize new vocabulary. Meanwhile, the two-semester program tended to result in students forgetting the vocabulary obtained at the beginning of the program. This study was intended to provide an extensive reading material with local wisdom to motivate students in learning English based on the students' expectations of a local-content book and make an initial evaluation of the book published afterward. The initial evaluation was conducted to investigate the effectiveness of the book created as an extensive reading material for the learning.

\section{Method}

Considering that the output of this study is in the form of a book, this research adopted a developmental research design. The ADDIE (Analysis, Design, Development, Implementation, and Evaluation) development model was then selected because this model has been claimed to be the most widely used by teaching material developers and has helped them develop teaching materials both on the online and offline platform (Aldoobie, 2015). As the name suggests, this model consists of five stages which include a number of stages from Analysis to Evaluation. However, due to the limited time I had, this paper only presents data from the three initial stages of ADDIE, namely Analysis, Design and Development. This study involved 187 participants who were currently studying at different faculties at the Tanjungpura University, West Kalimantan. They were invited to participate in an online survey about reading habits and cultural information. The survey results were then used as a guide before the book sample was actually created. In this study, the data were analyzed quantitatively. The analysis model used was descriptive analysis, aiming to provide a detailed description of the research findings. The results were used to determine the book content, difficulty level and format. In addition, upon completing the design, dummy books and follow-up questions were also provided for preliminary evaluations which served as an input to finalize the book and in the next stage the implementation of the book as teachinglearning material was carried out in different research. The next phase covered the development of the book features and produced an initial draft. The draft itself has been translated into English and carefully proofread to ensure that it is suitable for publication and has obtained an ISBN. In the future, this ISBN-assigned book can still be revised and commented on by experienced experts in their respective fields. Suggestions for the improvement of the book were also received through academic meetings such as conferences I attended during the research process

\section{Result and Discussion}

\section{Results \\ Analysis Stage}

This study collected two types of data from participants focusing on information about students' reading habits and their knowledge of local culture. Local culture is specified to the well-known traditional markets in Pontianak which are also the main focus of this book. In the first part, this study investigated how much participants enjoy reading, which books or reading sources (printed or electronic) they enjoy and often read, the participants' reading duration and the barriers they face while reading. Before responding to this online 
questionnaire, they had been told that all the questions in the questionnaire were related to books or articles written in English. Table 1 shows that nearly three-quarters of the student participants enjoy reading as indicated by $74.9 \%$ of them stating they like reading. However, this quite encouraging number does not automatically reflect that they often read. From the data, it can be seen that only $50.3 \%$ or about half of the total participants read frequently. However, this number is not too discouraging, because at least more than half of these young people still read frequently. In general, participants enjoyed reading. When asked if they liked reading books, the percentage of 'enjoy reading' decreased slightly to $64.7 \%$. In this digital era, it is not surprising when the survey results show that more participants read books in an electronic format rather than printed ones, namely 117 out of 187 participants or $62.6 \%$ declaring so. As for the forms of books that they preferred to read, it turns out that they also preferred electronic although the percentage difference is not too significant, namely $53.5 \%$ for electronic books and $46.5 \%$ for printed books. Table 2 shows that most of the participants read between $0-2$ hours $(52.4 \%)$. Of the 187 students who participated in this survey, only $17.6 \%$ of them read more than 2 hours a day.

Table 1. Percentage of enjoyment and frequency of reading by students of Tanjungpura University

\begin{tabular}{lcc}
\hline \multicolumn{1}{c}{ Description } & Number (of participants) & Percentage \\
\hline Enjoy reading & 140 & $74,9 \%$ \\
Read often & 94 & $50,3 \%$ \\
Enjoy reading books & 121 & $64,7 \%$ \\
Often read printed books & 70 & $37,4 \%$ \\
Often read electronic books & 117 & $62,6 \%$ \\
Enjoys reading printed books & 87 & $46,5 \%$ \\
Enjoy reading electronic books & 100 & $53,5 \%$ \\
\hline
\end{tabular}

Table 2. Percentage of reading Duration by students of Tanjungpura University

\begin{tabular}{lcc}
\hline \multicolumn{1}{c}{ Duration } & Number (of participants) & Percentage \\
\hline$<1$ hour & 98 & $52.4 \%$ \\
$1-2$ hours & 56 & $29.9 \%$ \\
$2-4$ hours & 15 & $12 \%$ \\
$>4$ hours & 18 & $9.6 \%$ \\
\hline Total & $\mathbf{1 8 7}$ & $\mathbf{1 0 0} \%$ \\
\hline
\end{tabular}

The participants' low interest in reading English books is clearly shown in Table 3. A total of $62.5 \%$ or as many as 117 participants stated that they did not like reading books or other items in English. Only 37.4\% state that they enjoy reading foreign language books. The research data also kept information about problems that students often face when reading English books as illustrated in Table 4. The results showed that difficult vocabulary is a major challenge for participants (58\%). The rest revealed that academic constraints and lack of motivation are significant factors in preventing them from reading English books with a percentage of $18.7 \%$ and $12.3 \%$, respectively. Only about $4.8 \%$ of participants stated that English books are usually not interesting so that they have no good reason to read them. The same percentage was also obtained from the number of students who thought that books and other reading materials in English are difficult to find. Only 1 person $(0.5 \%)$ stated the book content being too long as the reason for preventing reading from English resources. 
Table 3. Percentage of enjoyment of reading books or other Resources in English by students of Tanjungpura University

\begin{tabular}{lcc}
\hline \multicolumn{1}{c}{ Description } & $\begin{array}{c}\text { Number (of } \\
\text { participants) }\end{array}$ & $\begin{array}{c}\text { Percentag } \\
\text { e }\end{array}$ \\
\hline Not Enjoy reading books/other resources in & 117 & $62.6 \%$ \\
English & & 70 \\
Enjoy reading books/other resources in English & $\mathbf{1 8 7}$ & $\mathbf{3 7 . 4 \%}$ \\
\hline Total & $\mathbf{1 0 0 \%}$ \\
\hline
\end{tabular}

Table 4. Percentage of constraints of reading books in English by students of Tanjungpura University

\begin{tabular}{|c|c|c|}
\hline Constraint & Number (of participants) & Percentage \\
\hline Uninteresting book & 9 & $4.8 \%$ \\
\hline Too many difficult words & 110 & $58.8 \%$ \\
\hline Lack of motivation & 23 & $12.3 \%$ \\
\hline $\begin{array}{l}\text { Difficulty in finding books and other } \\
\text { reading materials in English }\end{array}$ & 9 & $4.8 \%$ \\
\hline The book being too long & 1 & $0.5 \%$ \\
\hline $\begin{array}{l}\text { Busy with college assignments or } \\
\text { other activities }\end{array}$ & 35 & $18.7 \%$ \\
\hline
\end{tabular}

In the next section, the participants were asked about their experiences in reading books containing cultural information. In addition, they were also asked about the traditional markets Pontianak City they knew about. They were also asked if they would be the potential buyers of the book, what information they would like to read in the book and at what price they could afford to buy the book. Table 5 below emphasizes that about three-quarters (75.4\%) of the participants have found and read books containing local content of West Kalimantan province; $16.6 \%$ of the participants responded that they are even unable to remember reading such a book. Those who have never read the book only reached $8 \%$. This suggests that the future of books containing local culture is still quite promising which makes me eager to complete this extensive local culture themed book.

Table 5. Percentage of having experienced on reading local culture themed books by students of Tanjungpura University

\begin{tabular}{lcc}
\hline \multicolumn{1}{c}{ Option } & Number (of participants) & Percentage \\
\hline Yes & 141 & $75.4 \%$ \\
No & 15 & $8 \%$ \\
Forget & 31 & $16.6 \%$ \\
\hline Total & $\mathbf{1 8 7}$ & $\mathbf{1 0 0} \%$ \\
\hline
\end{tabular}

Meanwhile, the next questions were made to investigate the popular traditional markets that they had knowledge about in their hometown, Pontianak. It was possible for the participants to name more than one market (Table 6). After making observation on the traditional markets in Pontianak, I selected thirteen markets which are quite well known in this city and have become favorite shopping places for the local people. Of the 13 existing traditional markets, the Flamboyan market is considered the most popular among the participants because nearly one third of them mentioned it, namely 58 participants or $31 \%$. According to the facts stated in the book "Popular Traditional Markets in Pontianak: A Guide Book for Learning English", this market is the largest and offers the most wide range of daily needs for the Pontianak people. It is not surprising that this market ranks as the most popular market according to the participants. The next popular traditional markets that rank third to sixth respectively are Pasar Tengah (Central Market), Pasar Pagi Sepakat (Sepakat Morning Market), Pasar Kemuning (Kemuning Market), Pasar Sudirman (Sudirman Market), and 
Pasar Dahlia (Dahlia Market) with 19.3\%, 13.9\%, 11.8\%, 6.4\%, and 5.9\% rating respectively. The remaining seven do not seem very popular with the participants as indicated by their low percentage. Two of them get the same rate (1.6\%), namely Pasar Teratai (Teratai Market) and Pasar Rakyat Perbatasan (Border People Market). The two markets with the lowest percentage, Purnama Morning Market and Parit Besar Market, also had the same rate, $0.5 \%$. The other three markets received $3.7 \%, 2.7 \%$, and $1.1 \%$ rating respectively.

Table 6. Percentage of familiarity of Pontianak's popular traditional markets by students of Tanjungpura University

\begin{tabular}{|c|c|c|c|}
\hline No & Traditional Market & Number (of participants) & Percentage \\
\hline 1 & Flamboyan Market & 58 & $31 \%$ \\
\hline 2 & Central Market & 36 & $19.3 \%$ \\
\hline 3 & Sepakat Morning Market & 26 & $13.9 \%$ \\
\hline 4 & Kemuning Market & 22 & $11.8 \%$ \\
\hline 5 & Sudirman Market & 12 & $6.4 \%$ \\
\hline 6 & Dahlia Market & 11 & $5.9 \%$ \\
\hline 7 & Ampera Afternoon Market & 7 & $3.7 \%$ \\
\hline 8 & Puring Market & 5 & $2.7 \%$ \\
\hline 9 & Teratai Market & 3 & $1.6 \%$ \\
\hline 10 & Border People's Market & 3 & $1.6 \%$ \\
\hline 11 & Melati Market & 2 & $1.1 \%$ \\
\hline 12 & Purnama Market & 1 & $0.5 \%$ \\
\hline 13 & Parit Besar Market & 1 & $0.5 \%$ \\
\hline
\end{tabular}

When asked about their interest in reading English books about traditional markets, almost all participants (177 of them or $94.7 \%$ ) give positive responses. About half or $50.3 \%$ are definitely interested in reading the book on this topic, while $44.4 \%$ stated that they were likely to be interested in reading book in a foreign language with the local context. Only 10 participants or 5.3 percent state that they are not interested in reading English textbooks on the topic of traditional markets. When asked about the aspects that participants would like to know from the book, they give positive responses as shown in Table 7. In these questions, it was possible for them to check more than one option. More than half of the participants are eager to read about the uniqueness of each market. It seems that they $(55.1 \%)$ are eager to know what makes each market different from the other. The second aspect that the participants want to know about traditional markets is what goods are offered there. A total of $37.4 \%$ think this aspect needs to be discussed in this book. Two other aspects that need to be covered in the book are the year these markets were founded $(5.9 \%)$ and location $(1.6 \%)$.

Table 7. Percentage of preference of book elements by students of Tanjungpura University

\begin{tabular}{lcc}
\hline \multicolumn{1}{c}{ Elements } & Number (of participants) & Percentage \\
\hline Uniqueness & 103 & $55.1 \%$ \\
Staple goods offered & 70 & $37.4 \%$ \\
Year of establishment & 11 & $5.9 \%$ \\
Location & 3 & $1.6 \%$ \\
\hline Total & $\mathbf{1 8 7}$ & $\mathbf{1 0 0} \%$ \\
\hline
\end{tabular}

\section{Design Process Stage}

The results in the analysis stage provided me with information needed in the book design planning process. For example, the data on the reading habits of the participants made it easier for me to determine the difficulty level of the book. Then, the majority of participants who read more often and enjoy reading electronic books became a separate consideration for allowing access to e-books or electronic books other than in print for target readers at a later date. 


\section{Development Stage}

This is the third stage of the ADDIE model and the last stage of this paper. At this stage, I began to produce the actual book. The book was carefully edited using special book editing software, called Adobe InDesign.

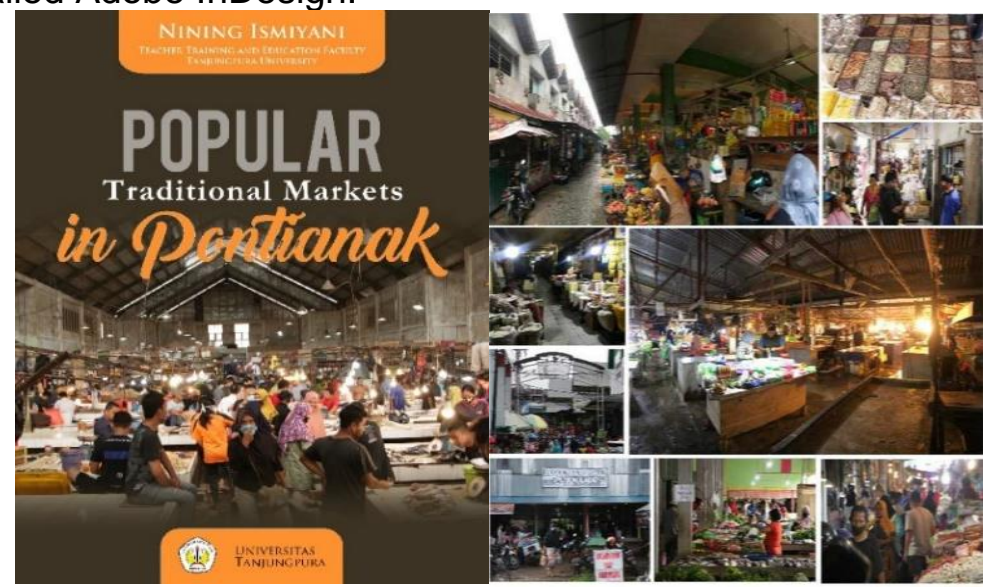

Figure 1. Book Cover (left) and a page of Teratai Market image (right)/ taken from the book "Popular Traditional Markets in Pontianak" - Nining Ismiyani

In this stage of development, I also conducted initial evaluations to ensure that this book is indeed interesting and worth reading. After the book layout had been completed, I sent the dummies in an electronic form to the participants and asked them to provide feedback on the book that had been created on a linear scale. The results of a brief survey showed that the book Popular Traditional Markets in Pontianak tended to be easier to learn and understood compared to English textbooks in general. Figure 1 shows that $61 \%$ of the participants agree with the book practical use. The participants $(63.1 \%$ in total) also think that the vocabulary provided in each chapter is very helpful for reading comprehension. This can be seen in Figure 2.

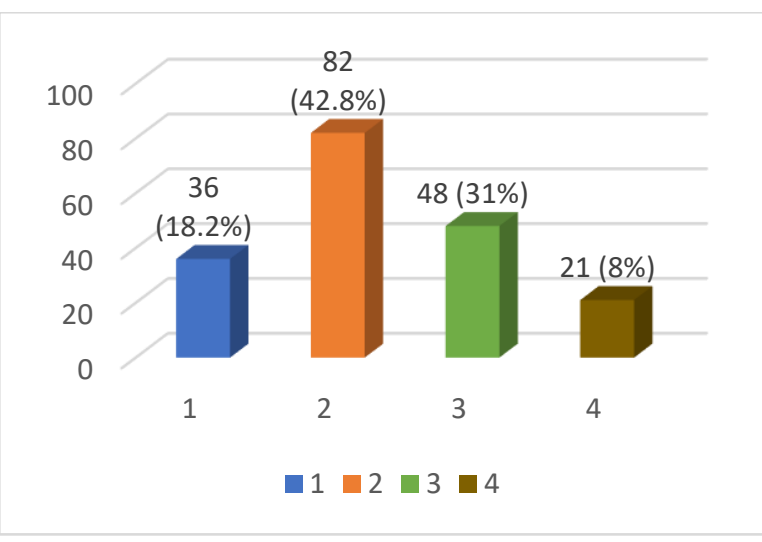

Figure 1. Level of Difficulty of the Book

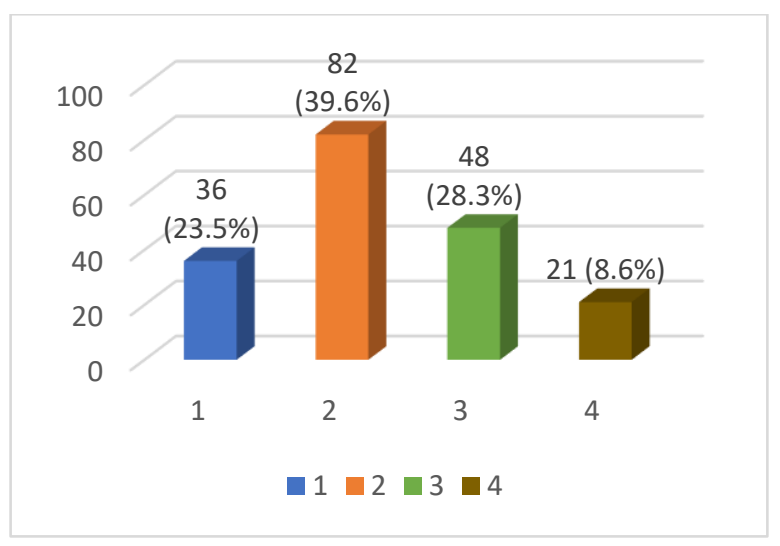

Figure 2. Vocabulary Effectiveness

Lastly, more than half of the participants agree that the book Popular Traditional Market in Pontianak is interesting to read. A total of $63.1 \%$ (39.6\% agree; $23.5 \%$ agree) of participants have a positive response to the presence of this extensive local-themed book, while the rest $(36.1 \%$ in total) do not find this book interesting for them. However, in general it is no exaggeration to say that this book is worth reading or interesting to read. In the next research, I will continue with the two advanced stages (Implementation and Evaluation) and it is expected that this book will get authentic positive responses. Future evaluation results will be used for revisions to produce a better book content and layout. 


\section{Discussion}

The findings of this study prove that a guide book for learning English with local wisdom could be utilized and interested for students of higher education and is not merely effective for students of elementary and secondary levels (Agustina \& Harahap, 2018; Florentino, 2014; Kusuma, 2012; Relin et al., 2018; Saputri, 2020; Suastra et al., 2017). Those studies on learning English through local wisdom also did not touch traditional market and more to the generally typical topics of local wisdom to mention politics, historical kingdoms, and tourism objects. Traditional Market is a simple topic adapted from local environment that is emerged with people's daily routines that it could facilitate the readers or the learners to engage with the reading and therefore allow them to understand the text easily as well as to learn English effectively. The initial evaluation of the researched published book shows that students are encouraged to learn English with the book adopting local context, that is Traditional Market. The details of the discussion are discussed as follows. From the findings in the analysis stage, it is discovered that the majority of the students enjoy reading. By the students liking this reading activity, implementing extensive reading for learning English is then not a burdening task because they have shown to have internal motivation for reading. Intrinsic motivation is important to make students develop a sense of belongingness (Ryan \& Deci, 2000), in this case towards the reading which can enrich their knowledge. Unfortunately, although the participants admit that they enjoy reading, most of them are not interested in reading English books. According to them, vocabulary is the biggest constraint for them to enjoy reading the materials in this foreign language. The deficits in vocabulary is one of major problems and reading difficulties for EFL learners (Davoudi \& Yousefi, 2015).

The fact that the majority of the students have experienced in reading books containing local content of West Kalimantan province, although in Indonesian language, will smoothen the use of the intended extensive reading material with local content to learn English. Their familiarity of the environment and local values is supposed to facilitate them in comprehending English books with local wisdom because they have backround knowledge towards the material. Background knowledge is in fact crucial to reduce the EFL learners' reading difficulties (Samad et al., 2017). Therefore, as the data revealed that the participants are familiar with the traditional markets discussed in the designed book entitled "Popular Traditional Markets in Pontianak", it is not exaggerating to verbalize that the students' background knowledge with the reading topics will enable them to comprehend the texts in the book quite easily. From the data, all traditional markets listed are well-known by the participants and Pasar Flamboyan is the most recognized one in the researched city.

The data also demonstrate that nearly a hundred per cent of students gave positive responses in reading English books about traditional markets and more than half of the participants are eager to read about the uniqueness of each market. What goods are offered there, the year these markets were founded, and location are other aspects that students would like to discover from the designed book. The book "Popular Traditional Markets in Pontianak" was finally designed and published based on the students' expectations in the initial survey. It is definitely expected that the discussed book will allow the students to engage with the reading naturally, without being too much aware of the process of learning as they get involved with the activity, and therefore become good readers. Good readers identify correctly the linguistic features such as words and gramatical structure without being aware of the process they engage in it (Lily, 2014).

The lack of local wisdom content is a major problem among Asian students, making them struggle to understand texts from different social cultures (Xie, 2017). To accommodate this, I asked the participants about several popular traditional markets in their vicinity in addition to obtaining this information from my own observations of the community in the subdistricts where these markets are located. Previous study discussed the experience of students' prior knowledge on a topic that is able to activate their schemata which facilitate them to better understand the text (Abdelaal \& Sase, 2014). I paid close attention to this aspect and took the suggestions given by the participants in Table 7 above. I introduced to the reader the uniqueness of the market, offered goods, year of establishment, and location. 
This book also provides additional information in hope of bringing it closer to the reader daily life.

At the development stage, I made efforts to help students visualize the traditional markets through representative pictures. In the selection process, images had to meet certain elements/criteria such as "pleasing to the eye and reflecting visual integrity" (Gunaydin \& Karamete, 2016). The real picture of the local population as shown in Figure 2 is expected to build a more original context so that it makes the reader feel like he is interacting with the indigenous population. An initial evaluation was conducted after the book was designed and published. The findings suggest that the majority of the participants admit that the book is easier to learn and understood compared to the available English books in general. They also stated that the vocabulary provided in each text really helpful in understanding the text without necessarily consulting to the dictionary. Furthermore, most of them also find that the designed book is interesting and therefore is worth reading. This proves that the effort to create the designed book is not useless. In other words, the localthemed book can encourage the learners to engage in the reading and motivate the learners to learn English. Motivation, besides language skill, is one of the main factors that contribute to one's success in improving reading comprehension abilities (Grabe \& Stoller, 2011).

\section{Conclusions and Suggestions}

The results of the needs analysis showed that the majority of the participants did not have good English skills and regular reading habits. The English materials bringing students' local wisdom are in fact approved to be necessary for these students to enhance their motivation to learn English. The initial evaluation convinces that the participants agree that the book designed is engaging and helpful for their English learning. However, this study still has limitations. It did not involve a large number of participants, so that the data or results cannot be generalized to other students throughout Indonesia. In addition, due to mobility and time constraints, this study still used the first three stages of the ADDIE model. More comprehensive results could have been produced if all stages had been covered. This will be my "homework" for the future research design. Finally, any suggestions and feedback for further improvement of the book are welcome.

\section{References}

Abdelaal, N. M., \& Sase, A. S. (2014). Relationship between Prior Knowledge and Reading Comprehension. Advances in Language and Literary Studies, 5(6), 125-131. https://eric.ed.gov/?id=EJ1128860.

Agustina, L., \& Harahap, A. (2018). Developing Reading Material Based-on Local Culture For Junior High School In Kabupaten Rejang Lebong. Journal of Applied Linguistics and Literature, 3(1). https://doi.org/10.33369/joall.v3i1.6169.

Ahmadi, M. R., \& Pourhossein, A. G. (2012). Reciprocal teaching strategies and their impacts on English reading comprehension. Theory and Practice in Language Studies, 2(10), 2053-2060. https://doi.org/10.1.1.736.2268.

Aka, N. (2019). Reading performance of Japanese High School Learners Following A OneYear Extensive Reading Program. Reading in a Foreign Language, 31(1), 1-18. https://eric.ed.gov/?id=EJ1212809.

Albantani, A. M., \& Madkur, A. (2018). Think Globally, Act Locally: The Strategy of Incorporating Local Wisdom in Foreign Language Teaching in Indonesia. International Journal of Applied Linguistics \& English Literature, 7(2), 1-8. http://dx.doi.org/10.7575/aiac.ijalel.v.7n.2p.1.

Anggraini, P., \& Kusniarti, T. (2017). Character and Local Wisdom-Based Instructional Model of Bahasa Indonesia in Vocational High Schools. Journal of Education and Practice, 8(5), 23-28. https://eric.ed.gov/?id=EJ1133091.

Anzar, Anshari., \& Juanda. (2018). Research Material Development of Drama Appreciation Based on Local Wisdom on Student in Indonesian Literature and Language 
Education Program at Muhammadiyyah University of Makassar Indonesia. Journal of Language Teaching and Research, 9(1), 113-118.

Arifani, Y. (2016). Optimizing EFL Learners' sensitizing Reading Skill: Development of Local Content-Based Textbook. English Language Teaching, 9(5). https://doi.org/10.5539/elt.v9n5p1.

Chen, S. C., \& Chen, K. T. (2015). The Use of EFL Reading Strategies among High School Students in Taiwan. The Reading Matrix, 15(2), 155-156. https://eric.ed.gov/?id=EJ1075987.

Davoudi, M., \& Yousefi, D. (2015). Comprehension breakdown: A review of research on EFL learners' reading difficulty and problems. International Journal of Language and Applied Linguistics, 1(1), 58-72. https://www.khatesefid.com/journal/wpcontent/uploads/2015/09/special-issue. pdf\#page $=69$.

Florentino, L. O. (2014). Integrating Local Literature in Teaching English to First Graders under K-12 Curriculum. Theory and Practice in Language Studies, 4(7), 1344-1351. https://doi.org/10.4304/tpls.4.7.1344-1351.

Grabe, W. (2009). Reading in a second language: Moving from theory to practice. Cambridge University Press.

Grabe, W., \& Stoller, F. L. (2011). Teaching and researching reading. Pearson.

Gunaydin, S., \& Karamete, A. (2016). Material Development to Raise Awareness of Using Smart Boards: An Example Design and Development Research. European Journal of Contemporary Education, 15(1), 114-122. https://eric.ed.gov/?id=EJ1095994.

Hadi, A. (2017). The International Journal of Social Sciences The Internalization of Local Wisdom Value in Dayah Educational Institution. Jurnal IImiah Peuradeun, 5(2), 189200. https://doi.org/10.26811/peuradeun.v5i2.128.

He, M. (2014). Does Extensive Reading Promote Reading Speed? Reading, 14(1). https://readingmatrix.com/files/1-16541dh4.pdf.

Hung, D. M., \& Ngan, V. P. T. (2015). Investigating Reading Strategies Used by EFL Students at Dong Thap University. Asian Journal of Educational Research, 3(4), 1020.

Khoiri, A. (2016). Local Wisdom PAUD to Grow Student's Soft Skills (Study Cash: Development RKH On Science Learning). Indonesian Journal Of Early Childhood Education Studies, 5(1), 14-17. https://doi.org/10.15294/ijeces.v5i1.11271.

Kusuma, I. P. I. (2012). Developing Reading Material For Elementary Students in Tourism Area By Inserting Local Culture. Jeels (Journal of English Education and Linguistics Studies), 3(1). https://jurnal.iainkediri.ac.id/index.php/jeels/article/download/176/168.

Lily, Z. (2014). A Discussion of Linguistic Factors Relating to English Reading for Chinese Mongolian Students at Thong Dap University. Studies in Literature and Language, 9(3), 136-142. http://dx.doi.org/10.3968/n.

Liu, J., \& Zhang, J. (2018). The Effects of Extensive Reading on English Vocabulary Learning: A Meta-Analysis. English Language Teaching, 11(6), 1-15. https://doi.org/10.5539/elt.v11n6p1.

Mori, S. (2015). If you build it, it will come: From a "Field of Dreams" to a more realistic view of extensive reading in EFL context. Reading in a Foreign Language, 27(1), 129-135. https://eric.ed.gov/?id=EJ1059709

Muslich, M. (2010). Text Book Writing. Ar-ruzz Media.

Nakanishi, T. (2015). A Meta-analysis of Extensive Reading Research. TESOL Quaterly, 49(1), 6-37. https://doi.org/10.1002/tesq.157.

Nurfatuhiyah. (2017). Learning materials development on descriptive texts based on local culture as learning at junior high school. International Research Journal of Engineering, IT \& Scientific Research, 3(6), 39-55. https://sloap.org/journals/index.php/irjeis/article/view/9.

Parmin, Sajidan, Ashadi, Sutikno, \& Maretta, Y. A. (2016). Preparing Prospective Teachers in Integrating Science and Local Wisdom through Practicing Open Inquiry. Journal of Turkish Science Education, 13(2), 3-14. https://doi.org/10.12973/tused.10163a.

Relin, R., Rasna, I. W., \& Binawati, W. S. (2018). Local Wisdom Values in Balinese Folktales 
That Are Relevant to Character Education for the First Grade at Primary School. Journal of Language Teaching and Research, 9(1), 155-163. https://core.ac.uk/download/pdf/266996466.pdf.

Rena. (2014). Pengaruh Buku Penunjang Sebagai Sumber Belajar terhadap Motivasi dan Hasil Belajar Siswa pada Mata Pelajaran Geografi di Madrasah Aliyah Alkhairaat Tondo Palu. E Journal Geo-Tadulako UNTAD.

Renandya, W. A., \& Jacobs, G. M. (2016). Extensive Reading and Listening in the L2 Classroom. English Language Teaching Today.

Ryan, R. M., \& Deci, E. L. (2000). Intrinsic and extrinsic motivations: Classic definitions and new directions. Contemporary Educational Psychology, 25(1), 54-67. https://doi.org/10.1006/ceps.1999.1020.

Samad, I. A., Jannah, M., \& Fitriani, S. S. (2017). EFL Students' Strategies Dealing with Common difficulties in TOEFL Reading Comprehension Section. International Journal of Language Education, 1(1), 29-36. https://doi.org/10.26858/ijole.v1i1.2869.

Saputri, S. W. (2020). Developing English Teaching Materials based Local Wisdom: Is it Effective to Improve Student's Learning Outcomes at SMKN 1 Cinangka? Asian EFL Journal, 27(5.2), 91-96.

Suastra, I. W., Jatmiko, B., Ristiati, N. P., \& Yasmini, L. P. B. (2017). Developing characters based on local wisdom of bali in teaching physics in senior high school. Jurnal Pendidikan IPA Indonesia, 6(2), 306-312. https://doi.org/10.15294/jpii.v6i2.10681.

Suk, N. (2017). The effects of extensive reading on reading comprehension, reading rate, and vocabulary acquisition. Reading Research Quarterly, 52(1), 73-89. https://doi.org/10.1002/rrq.152.

Toharudin, U., \& Kurniawan, I. S. (2016). Values of Local Wisdom: A Potential to Develop an Assessment and Remedial. International Journal of Evaluation and Research in Education (IJERE), 6(1), 7-78. https://doi.org/10.11591/ijere.v6i1.6349.

Tomlinson, B. (2011). Introduction: Principles and procedures of materials development. Materials Development in Language Teaching, 2011, 1-31.

Waring, R., \& McLean, S. (2015). Exploration of the core and variable dimensions of extensive reading research and pedagogy. Reading in a Foreign Language, 27(1), 160-167. https://core.ac.uk/download/pdf/323110107.pdf.

Xie, X. (2017). the Influence of Schema Theory on Foreign. The English Teacher, XXXIV, $67-75$.

https://citeseerx.ist.psu.edu/viewdoc/download?doi=10.1.1.568.4106\&rep=rep1\&type $=$ pdf. 